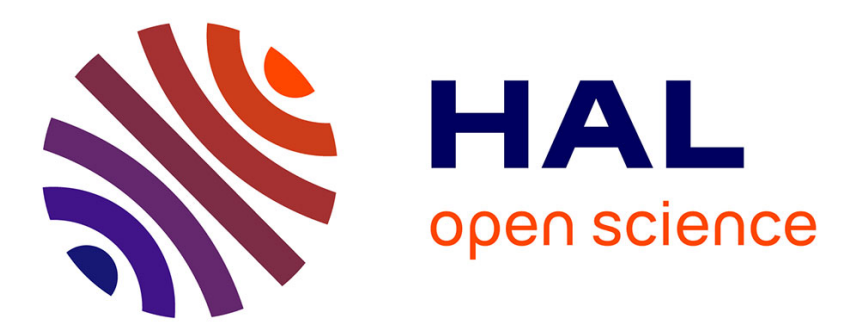

\title{
Tumour-targeting photosensitisers for one- and two-photon activated photodynamic therapy
}

Sébastien Jenni, Angélique Sour, Frédéric Bolze, Barbara Ventura, Valérie

Heitz

\section{- To cite this version:}

Sébastien Jenni, Angélique Sour, Frédéric Bolze, Barbara Ventura, Valérie Heitz. Tumour-targeting photosensitisers for one- and two-photon activated photodynamic therapy. Organic \& Biomolecular Chemistry, 2019, 17 (27), pp.6585-6594. 10.1039/c9ob00731h . hal-02361931

\section{HAL Id: hal-02361931 \\ https://hal.science/hal-02361931}

Submitted on 8 Jan 2021

HAL is a multi-disciplinary open access archive for the deposit and dissemination of scientific research documents, whether they are published or not. The documents may come from teaching and research institutions in France or abroad, or from public or private research centers.
L'archive ouverte pluridisciplinaire HAL, est destinée au dépôt et à la diffusion de documents scientifiques de niveau recherche, publiés ou non, émanant des établissements d'enseignement et de recherche français ou étrangers, des laboratoires publics ou privés. 


\section{Tumour-Targeting Photosensitisers for One- and Two-photon Activated Photodynamic Therapy}

Received 00th January 20xx, Accepted 00th January 20xx DOI: $10.1039 / \times 0 \times x 00000 x$ hal-02361931>

\begin{abstract}
Sébastien Jenni, ${ }^{a}$ Angélique Sour, ${ }^{\mathrm{a}}$ Frédéric Bolze, ${ }^{* \mathrm{~b}}$ Barbara Ventura ${ }^{\mathrm{c}}$ and Valérie Heitz ${ }^{* \mathrm{a}}$
Despite the advantages of photodynamic therapy (PDT) over chemotherapy or radiotherapy such as low side effects, lack of treatment resistance and spatial selectivity inherent to light activation of the drug, several limitations especially related to the photosensitiser (PS) prevent PDT from becoming widespread in oncology. Herein, new folic acid- and biotinconjugated PSs for tumour-targeting PDT are reported, with promising properties related to PDT such as intense absorption following one-photon excitation in the red or two-photon excitation in the near-infrared, and also high singlet oxygen quantum yield (close to $70 \%$ in DMSO). Cellular studies demonstrated that both targeted PSs induced phototoxicity, the folate-targeted PS being the most effective one with $80 \%$ of cell death following 30 min of irradiation and a phototoxicity four times higher than that of the non-targeted PS. This result is in accordance with the uptake of the folate-targeted PS in HeLa cells, mediated by the folate receptors. Moreover, this folate-targeted PS was also phototoxic following two-photon excitation at $920 \mathrm{~nm}$, opening new perspectives for highly selective PDT treatment of small and deep

tumours.
\end{abstract}

\section{Introduction}

Photodynamic therapy (PDT) is a non-invasive clinically approved treatment which has shown its efficiency in cancer therapy, ophthalmology and dermatology. ${ }^{1,2}$ In PDT the photosensitiser (PS), a non-toxic drug activated by light absorption, reacts with surrounding oxygen to generate reactive oxygen species that damage cells, tissue and vasculature. The selectivity of the treatment provided by the local photoactivation of the PS, and the absence of induced resistance to such treatment, have encouraged researchers to overcome the limitations of PDT in its current application to cancer. Among these limitations is the light-activation of the PS, which is usually performed in the visible range and not in the optical therapeutic window, between 700 and $950 \mathrm{~nm}$. Light excitation in this spectral range ensures minimal absorption by endogenous chromophores, limited photodamage to healthy tissue, increased penetration of light into tissue and thus deeper treatment. Therefore, a new generation of PSs with lower HOMO-LUMO gap and absorption shifted towards the near infrared was designed. ${ }^{3-5}$ More recently, excitation performed in the optical therapeutic

Laboratoire de Synthèse des Assemblages Moléculaires Multifonctionnels, Institut de Chimie de Strasbourg, CNRS/UMR 7177, Université de Strasbourg, 4, rue Blaise Pascal, 67000 Strasbourg (France).E-mail: v.heitz@unistra.fr

b. CAMB, UMR 7199, UdS/CNRS, Faculté de Pharmacie, Université de Strasbourg, 74 route du Rhin, 67401 IIIkirch (France). E-mail : frederic.bolze@unistra.fr

Istituto ISOF-CNR, Via P. Gobetti 101, 40129 Bologna (Italy). E-mail :

barbara.ventura@isof.cnr.it

Electronic Supplementary Information (ESI) available: $\left[{ }^{1} \mathrm{H},{ }^{13} \mathrm{C}\right.$ NMR and HR ES-MS of the synthesized compounds, singlet oxygen quantum yield determination and confocal microscopy]. See DOI: 10.1039/x0xx00000x window was conceived with a non-linear optical process called two-photon excitation, predicted in the early 1930 s. $^{6}$ Twophoton PDT requires the use of short-pulse lasers to generate a high density of photons as well as new PSs with large $\pi$ conjugated donor-acceptor system that have a high twophoton absorption cross section in the near-infrared. ${ }^{7}$ Twophoton absorption occurs in a minimal volume around the focal point of the laser and therefore provides a high precision to the PDT treatment, as already shown with vascular closure on mice models and eradication of small tumours. ${ }^{7-11}$ Enhancing the selectivity of the PS for the tumour is another goal to improve PDT. Increasing the PS localization in the tumour using the active targeting strategy ${ }^{12,13}$ will increase the efficiency of the treatment, while allowing for a decrease of the PS dose and of the photodamage of healthy tissue. Targeted PS for receptor-mediated delivery of the PS in tumours were reported by conjugation with monoclonal antibodies, ${ }^{14}$ carbohydrates, ${ }^{15-19}$ and steroids. ${ }^{20}$ Small targeting biomolecules such as peptides ${ }^{21-30}$ or vitamins ${ }^{31-38}$ were also conjugated to increase the uptake of the PS in tumour tissue. Another strategy relies on the use of nanomaterials and examples of passive tumour targeting with various nanoformulations or of active targeting with nanoparticles incorporating both PSs and targeting agents, have been reported. ${ }^{39-42}$ Nevertheless, combining two-photon activatable molecular PS in the near infra-red for high spatial selectivity and deep tumour treatment, with targeting units for enhanced delivery of the PS has not received much attention yet. ${ }^{10,43-45}$

We previously reported on the design of new molecular porphyrin-based PSs for PDT connected to imaging agents for 
magnetic resonance imaging. These theranostic agents were able to kill cancer cells following classical one-photon excitation $^{46}$ or following two-photon excitation in the nearinfrared. ${ }^{47,48}$ Based on the promising results obtained with an engineered $\pi$-extended porphyrin in two-photon excited PDT, ${ }^{49}$ our purpose became the enhancement of the selectivity of the PS with the addition of a tumour-specific vector targeting either folate or biotin receptors, known to be overexpressed on the surface of many tumours. Folic acid (vitamin B9) $^{35,50,51}$ and biotin (vitamin B7) ${ }^{52}$ are growth cell promoters and consumed to a great extent in cancerous cells. Both have shown to be valuable targets in the context of $\mathrm{PDT}^{29}, 31,36,38,44,53-68$ with promising preclinical studies reported on the selectivity of folate-conjugated porphyrins for peritoneal metastasis of epithelial ovarian cancer. ${ }^{53}$

Herein, the synthesis of two targeted PSs, consisting of $\pi$ extended diketopyrrolopyrrole-porphyrin conjugates connected to folic acid or biotin is reported, as well as a comprehensive study on their photophysical properties (fluorescence quantum yields and lifetimes, singlet oxygen quantum yields, and two-photon cross sections). Moreover, the photodynamic activity of the two PSs following onephoton excitation was assessed on cancer cells. For the most promising PS that targets folate receptors, the two-photon induced toxicity with excitation in the optical therapeutic window at $920 \mathrm{~nm}$ was also evaluated.

\section{Results and discussion}

\section{Synthesis and characterization}

The folic acid- and the biotin-functionalized PSs, respectively 1 and $\mathbf{2}$, are represented in Scheme 1 . Their synthesis involved a common porphyrinic precursor 5 (Scheme 2) reported in our previous work. ${ }^{47}$ This precursor consists of a $\pi$-delocalized diketopyrrolopyrrole-Zn(II) porphyrin conjugate decorated with several mono- and tri-ethyleneglycol chains to avoid aggregation in water and to make the PS amphiphilic for cellular uptake. Furthermore the large $\pi$-conjugated system of 5 has been shown to endow this PS with two-photon absorption in the near infrared. ${ }^{69}$
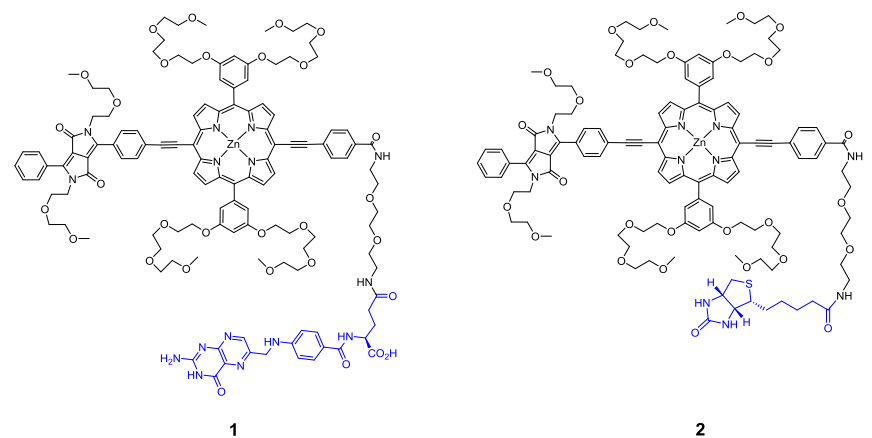

Scheme 1. Chemical structures of the folic acid- and biotin-targeted PSs $\mathbf{1}$ and $\mathbf{2}$.

To connect the PS to the targeting agents, a short hydrophilic linker $\mathbf{3}$ was selected according to the study by Frochot and co- workers on polyethylene glycol connectors in the context of folate-targeted PSs (Scheme 2). ${ }^{54}$ Compound 3 was reacted with $p$-iodobenzoic acid in DMF, using TBTU $(2-(1 \mathrm{H}-$ benzotriazole-1-yl)-1,1,3,3-tetramethylaminium tetrafluoroborate) as a coupling reagent and DIPEA ( $N, N$ diisopropylethylamine) as a base to afford 4 in $83 \%$ yield. A Sonogashira coupling reaction between 4 and the porphyrin precursor 5 afforded compound 6 in 75\% yield after purification by silica gel column chromatography. The Bocprotecting group (tert-butyloxycarbonyl) was then removed from 6 with classical conditions, using TFA (trifluoroacetic acid) in DCM. These conditions led to demetalation of the $\mathrm{Zn}(\mathrm{II})$ porphyrin, which was remetalated with $\mathrm{Zn}(\mathrm{OAc})_{2} \cdot 2 \mathrm{H}_{2} \mathrm{O}$ to afford the functionalized PS $\mathbf{7}$ in almost quantitative yield.

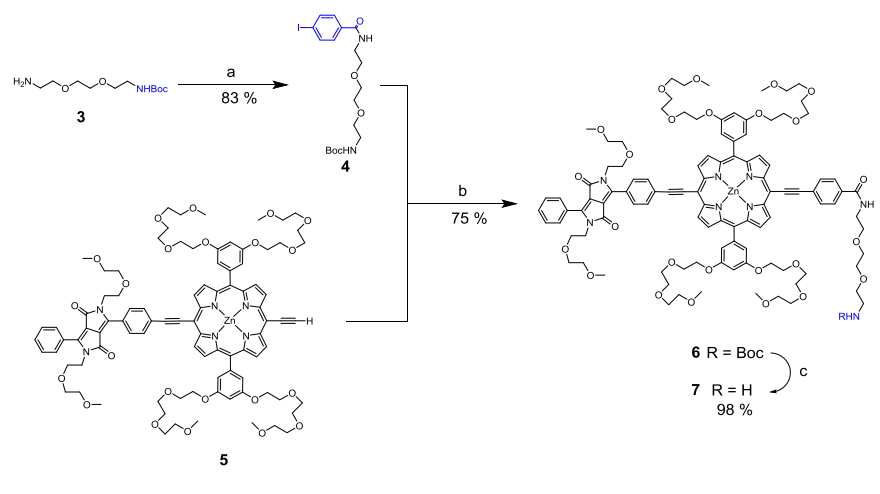

Scheme 2. Reagents and conditions : (a) $p$-iodobenzoic acid, TBTU, DIPEA, DMF (b) $\mathrm{Pd}\left(\mathrm{PPh}_{3}\right)_{4}, \mathrm{Cul},(\mathrm{iPr})_{2} \mathrm{NH}, \mathrm{THF}$; (c) 1) TFA, $\left.\mathrm{CH}_{2} \mathrm{Cl}_{2}, 2\right) \mathrm{Zn}(\mathrm{OAc})_{2} \cdot 2 \mathrm{H}_{2} \mathrm{O}, \mathrm{CHCl}_{3}$, $\mathrm{MeOH}$.

The synthesis of the two targeted PSs $\mathbf{1}$ and $\mathbf{2}$ is depicted in Scheme 3.

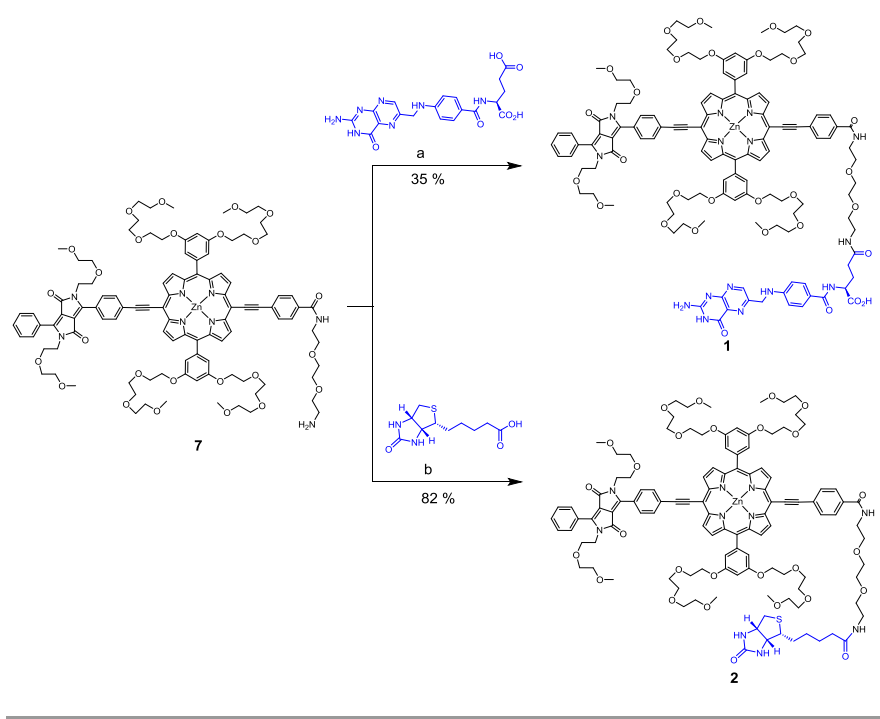

Scheme 3. Reagents and conditions: (a) TBTU, N-methylmorpholine, DMSO, DMF; (b) TBTU, DIPEA, DMF.

To synthesize the folic acid-PS conjugate 1 by the coupling reaction between 7 and folic acid, we selected the reaction conditions that were reported to promote the reaction at the 
less sterically hindered $\gamma$ carboxyl site of the two $\alpha$ and $\gamma$ carboxylic acids of folic acid. ${ }^{31,70}$ Thus, using TBTU in a solvent mixture of DMSO/DMF $(1 / 1, v / v)$ at $0^{\circ} \mathrm{C}$, the folic acidfunctionalized PS 1 was obtained in 35\% yield after purification on semi-preparative HPLC. The biotin-targeted PS $\mathbf{2}$ was obtained by coupling 7 and biotin using TBTU and DIPEA in classical reaction conditions. It was isolated in $82 \%$ yield after purification by flash chromatography followed by semipreparative HPLC. Both targeted PSs were characterized by ${ }^{1} \mathrm{H}$ NMR, ${ }^{13}$ C NMR and HR ESI-MS.

\section{One-photon photophysical characterization}

The linear absorption and fluorescence spectra of $\mathbf{1}$ and 2, measured in DMSO, are shown in Figure1a and $1 \mathrm{~b}$ respectively. Arbitrarily scaled absorption and emission spectra obtained in $\mathrm{H}_{2} \mathrm{O}$ added with $1 \%$ DMSO are shown in Figure S18. The absorption spectra in DMSO are similar to the one reported for 5 coupled to an aminobenzyl unit ${ }^{47}$. They show red shifted and broad Soret and $Q$ bands due to the extended conjugation of the porphyrin core to the peripheral diketopyrrolopyrrole and benzylamide components. Interestingly, both compounds show an intense $Q$ absorption band at $670 \mathrm{~nm}$ with epsilon around $60000 \mathrm{M}^{-1} \cdot \mathrm{cm}^{-1}$ comparable to the most-red absorption band of chlorin e6, ${ }^{71}$ a second generation PS approved for photodynamic diagnosis and therapy applications. Spectra in $\mathrm{H}_{2} \mathrm{O}$ with $1 \%$ DMSO are slightly broader than in DMSO (Figure S18), indicating moderate aggregation.
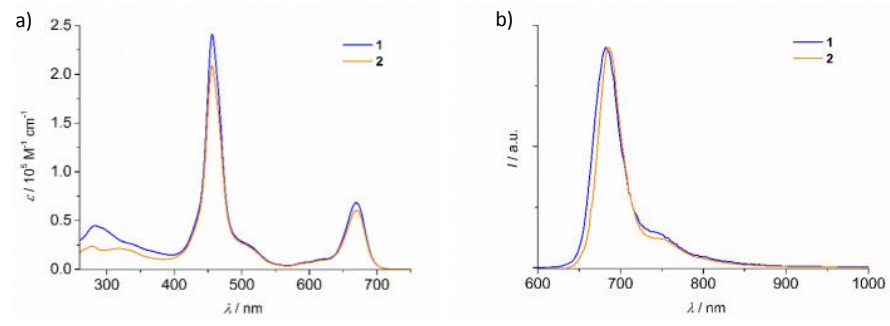

Figure 1. Absorption a) and normalized corrected emission b) spectra of $\mathbf{1}$ and $\mathbf{2}$ in DMSO.

Emission properties of $\mathbf{1}$ and $\mathbf{2}$ in DMSO and in $\mathrm{H}_{2} \mathrm{O}$ with $1 \%$ DMSO are collected in Table 1 . Both compounds show, in DMSO, emission maxima at 682-686 $\mathrm{nm}$, fluorescence quantum yields of 0.14 and excited state lifetimes close to 1 ns. These features are in line with those previously reported for a Zn-porphyrin connected, via acetylene linkers, to a DPP unit and a benzyl bridged secondary imaging agent, ${ }^{47}$ and are attributed to the large conjugation of the porphyrinic system. In $\mathrm{H}_{2} \mathrm{O}$ with $1 \%$ DMSO the emission spectra are broad and largely red-shifted with respect to DMSO, with tails extending up to $1200 \mathrm{~nm}$ (Figure S18). Quantum yields of the order of 3-6 $\times 10^{-3}$, i.e. about $20-40$ times lower than in DMSO, are measured and the fluorescence decays are fitted by biexponential functions, with short lifetime components of the order of 0.3-0.6 ns (Table 1). These results can be ascribed to the presence of aggregates in the aqueous solution, that turn out to be detrimental in terms of fluorescence output but improve the spectral extension of the emission in the biological window. Moreover, a good superimposition of excitation and absorption spectra is found in $\mathrm{H}_{2} \mathrm{O}$ with $1 \%$ DMSO as well as in pure DMSO (Figure S19), confirming the genuineness of the emission in both solvents.

Table 1. Luminescence data and singlet oxygen production quantum yields at room temperature in the different solvents.

\begin{tabular}{llllll}
\hline & & $\lambda_{\max } / \mathrm{nm}^{a}$ & $\phi_{\mathrm{fi}}{ }^{b}$ & $\tau / \mathrm{ns}^{c}$ & $\phi_{\Delta}{ }^{d}$ \\
\hline $\mathbf{1}$ & DMSO & $682,748 \mathrm{sh}$ & 0.14 & 0.94 & 0.69 \\
& $\mathrm{H}_{2} \mathrm{O}+1 \%$ DMSO & 744 & $6.0 \times 10^{-3}$ & $0.34(40 \%) ; 1.55(60 \%)$ & - \\
\multirow{2}{*}{$\mathbf{2}$} & DMSO & $686,754 \mathrm{sh}$ & 0.14 & 0.96 & 0.70 \\
& $\mathrm{H}_{2} \mathrm{O}+1 \%$ DMSO & 778 & $3.1 \times 10^{-3}$ & $0.62(75 \%) ; 1.94(25 \%)$ & -
\end{tabular}

${ }^{a}$ From corrected emission spectra. ${ }^{b}$ Fluorescence quantum yields, measured with reference to DPP-ZnP-DPP in aerated DCM $\left(\phi_{\mathrm{fl}}=0.16\right) .{ }^{49} \mathrm{c}$ Excited state lifetimes, excitation at $465 \mathrm{~nm}$ (in round brackets: fractional intensities). ${ }^{d}$ Singlet oxygen production quantum yields, see the Experimental Section for details.

The singlet oxygen quantum yields of $\mathbf{1}$ and $\mathbf{2}$ were determined, in DMSO, by using 1,3-diphenylisobenzofuran (DPBF) as a singlet oxygen trap, with reference to $\mathrm{Zn}$ phthalocyanine $\left(\mathrm{ZnPc}, \phi_{\Delta}=0.67\right)^{72}$ upon irradiation at $672 \mathrm{~nm}$. Figure $\mathrm{S} 20$ shows the changes in the absorption spectrum of a mixture of the examined compound (or standard) and DPBF upon irradiation at $672 \mathrm{~nm}$. The decrease of the DPBF absorption, due to its degradation upon reaction with the produced singlet oxygen, is monitored at $417 \mathrm{~nm}$ as a function of the irradiation time. The $\phi_{\Delta}$ value is calculated by comparison of the degradation rates measured for the compound and the standard and taking into consideration the absorption at the excitation wavelength of both the sample and the standard (see the Experimental Section for details). Following this procedure, $\phi_{\Delta}$ values of 0.69 and 0.70 are measured for $\mathbf{1}$ and $\mathbf{2}$, respectively (Table 1 ). These values are rather high for DPP-porphyrin conjugates and are comparable to those of red absorbing second-generation chlorin-based PSs. $^{71}$

The high capacity of these two targeted PSs to generate singlet oxygen, as well as their intense absorption of red light, evidence their potential as phototoxic agents following onephoton excitation.

\section{Two-photon absorption properties}

The two-photon absorption properties of $\mathbf{1}$ and $\mathbf{2}$ were studied by the two-photon induced fluorescence method as reported. ${ }^{49}$ The two-photon excitation spectra were recorded in DMSO only, as the low fluorescence quantum yield of the compounds in $\mathrm{H}_{2} \mathrm{O}$ prevents measurements in this media. The spectra are shown in Figure 2 with that of the TIPS-protected alkyne derivative of 5, DPP-ZnP (Scheme S1). Both targeted PSs display a large two-photon absorption between 920 and 980 $\mathrm{nm}$ with maxima at $940 \mathrm{~nm}$ and two-photon cross sections of about $1000 \mathrm{GM}$ (respectively 935 and $1115 \mathrm{GM}$ for $\mathbf{1}$ and 2). The two-photon cross-sections value obtained in the 920-980 $\mathrm{nm}$ range for the PSs with or without the targeting moieties are similar (with a value of $1007 \mathrm{GM}$ at $940 \mathrm{~nm}$ for DPP-ZnP) 
and show that these vectors do not inhibit the ability of the PS for two-photon absorption.

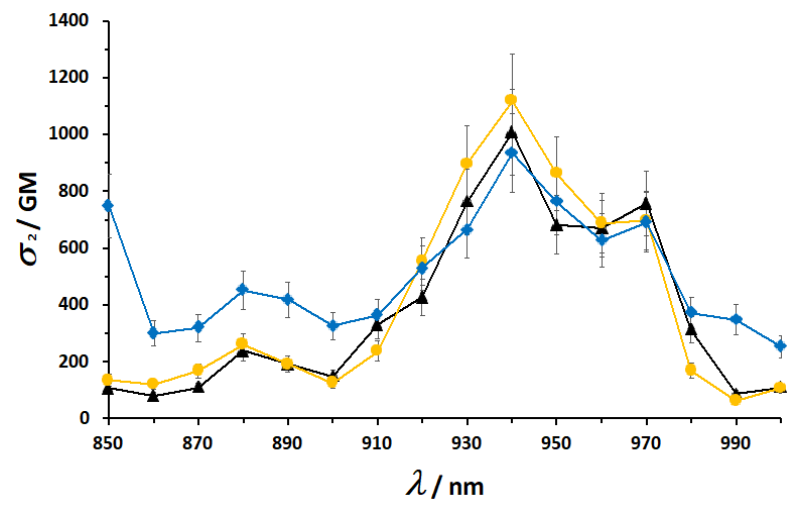

Figure 2. Two-photon excitation spectra of $\mathbf{1}$ (blue), $\mathbf{2}$ (orange) and DPP-ZnP (black) in DMSO.

\section{Cytotoxicity}

The toxicity of $\mathbf{1}$ and $\mathbf{2}$ in the absence of light was evaluated on HeLa cells, 24h after incubation with classical MTT test. Interestingly, whereas the compounds do not fluoresce in the incubation medium, the internalization of the compounds can be evidenced by their fluorescence with confocal microscopy $24 \mathrm{~h}$ after incubation (Figure S21), indicating interactions with cellular components. The cytotoxicity results are represented in Figure 3 and the half-maximal inhibitory concentration $\left(\mathrm{IC}_{50}\right)$ value obtained are 11 and $7 \mu \mathrm{M}$ for 1 and 2, respectively. Both PSs exhibited no dark toxicity at $1 \mu \mathrm{M}$ concentration, the concentration used to perform the phototoxicity experiments.

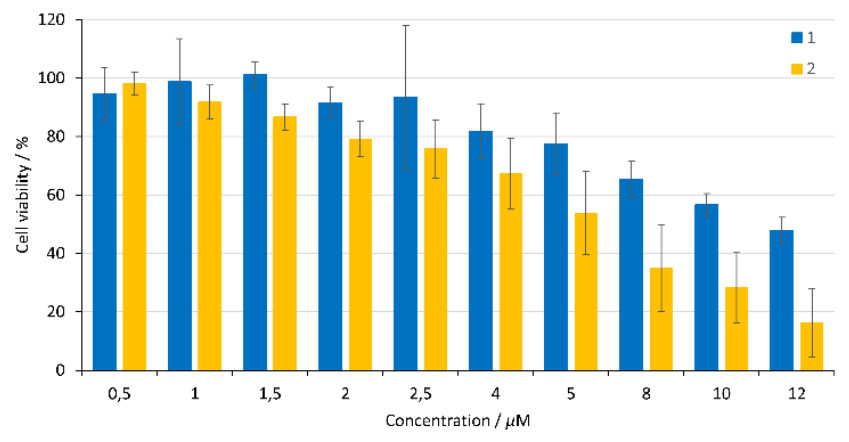

Figure 3. Cytotoxicity evaluation of $\mathbf{1}$ and $\mathbf{2}$ on HeLa cells after $24 \mathrm{~h}$ incubation. Error bars are standard deviation of at least 3 independent experiments.

\section{Competition assays}

Competition assays were performed on HeLa cells to show that the affinity of $\mathbf{1}$ and $\mathbf{2}$ for these cancer cells was mediated by the specific targeted receptors. ${ }^{57}$ HeLa cell line is known to overexpress both the biotin and the folate receptors compared to non-cancerous cell lines. ${ }^{52,73}$
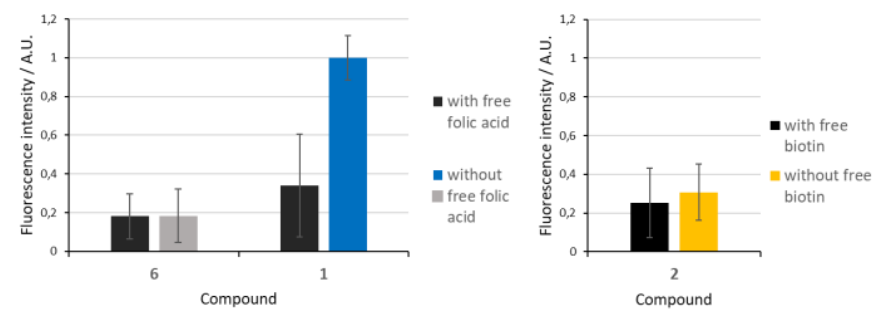

Figure 4. Fluorescence intensity of the PSs 1, 2 and $\mathbf{6}$ in HeLa cells in presence or in absence of an excess of free folic acid or biotin in the culture medium after 24 $\mathrm{h}$ incubation at $1 \mu \mathrm{M}$. The emission is proportional to the intracellular concentration of the compounds (see experimental section). Error bars are standard deviation of at least 3 independent experiments. Changer couleur 6

In the presence of excess folic acid in the culture medium, the internalization of the folate -targeted PS $\mathbf{1}$ is significantly decreased whereas for the non-targeted precursor $\mathbf{6}$, the presence of folic acid in the culture medium had no influence on its internalization (Figure 4). This is indicative of the strong ability of $\mathbf{1}$ to target folate-receptor-positive cells mediated by the folate receptors with more than $50 \%$ of its internalization suppressed when the receptors are saturated by free folic acid. For the biotin-targeted PS 2, there is no significant difference in the amount of internalized PS, in the presence or absence of an excess of biotin in the media. This result suggests that the biotin linked to the PS has no ability to target its receptor. This results is surprising since other groups have reported a zinc(II) phthalocyanine PS linked to biotin that showed higher internalization in cells that overexpressed biotin receptors. ${ }^{65,}$ 67,68

\section{One-photon phototoxicity}

The intense red absorption of $\mathbf{1}$ and $\mathbf{2}$ and their high singlet oxygen generation make these targeted PSs appealing candidates for classical one-photon PDT. Irradiation at $660 \mathrm{~nm}$ was thus performed on HeLa cells incubated at a concentration of $1 \mu \mathrm{M}$ for $24 \mathrm{~h}$ with $\mathbf{1 , 2}$ or $\mathbf{6}$, at a fluence of 36 $\mathrm{mW} / \mathrm{cm}^{2}$ for 15 or $30 \mathrm{~min}$. The cell viability was assessed $24 \mathrm{~h}$ after irradiation with MTT test and the results are shown in Figure 5. Neither $30 \mathrm{~min}$ irradiation at $36 \mathrm{~mW} / \mathrm{cm}^{2}$ without PS, nor the PSs 1, 2 or 6 incubated at $1 \mu \mathrm{M}$ without irradiation induced toxicity. Following $15 \mathrm{~min}$ irradiation, a decrease of cell viability was observed with the three incubated PSs, but the folate-targeted PS 1 had already induced $70 \%$ of cell death and was seven times more efficient than the non-targeted PS 6 (10\% of cell death). After $30 \mathrm{~min}$ irradiation, 6 induced only 20 $\%$ phototoxicity whereas the biotin-conjugate $\mathbf{2}$ induced $50 \%$ phototoxicity and the folic acid -conjugate 1, with more than $80 \%$ of cell death, was the most effective. These results are in line with those obtained in the accumulation assay experiments with 1 showing the highest accumulation in HeLa cells. They also confirm that the addition of targeting moiety strongly improves the efficiency of the PSs, since $\mathbf{1}$ and $\mathbf{2}$ are much more phototoxic than 6 . 


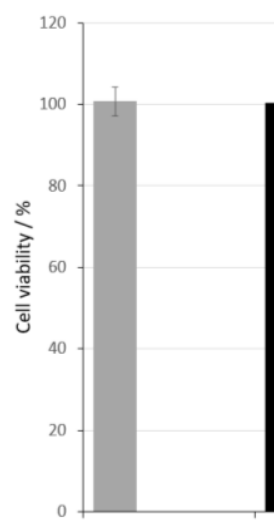

without PS 30 min irradiation

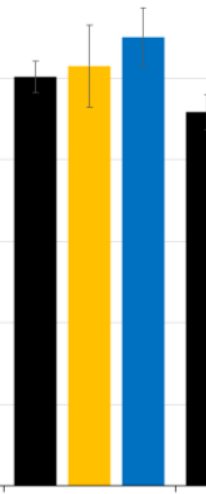

PS no irradiation

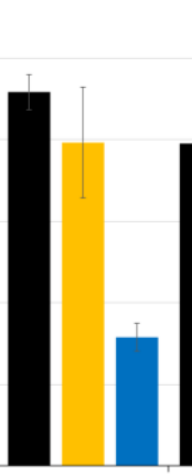

Figure 5. Viability of HeLa cells incubated with 1, 2 and $6(1 \mu \mathrm{M})$ for $24 \mathrm{~h}$ followed by 0,15 or $30 \mathrm{~min}$ of one-photon irradiation at $660 \mathrm{~nm}$ with a light intensity of $36 \mathrm{~mW} / \mathrm{cm}^{2}$. Cell viability was assessed $24 \mathrm{~h}$ after irradiation. Error bars are standard deviation of at least 3 independent experiments.

\section{Two-photon phototoxicity}

Compound 1 was selected for further PDT experiments following two-photon excitation based on its superior affinity for HeLa cells and higher one-photon induced toxicity than $\mathbf{2}$. Images were taken on cells incubated for $24 \mathrm{~h}$ with (Figure 6a) or without 1 (Figure $6 \mathrm{~d}$ ) before $3 \mathrm{~min}$ irradiation was performed at $920 \mathrm{~nm}$ with $12 \mathrm{~mW}$ laser power. Ten minutes after irradiation, some cells showed a morphology change (shrinkage) indicating cell death (Figure 6b). After $4 \mathrm{~h}$, a large number of cells were killed (Figure $6 \mathrm{c}$ ) and the phototoxicity was evaluated at $60 \%$. In the same conditions, the nonincubated cells did not show any morphological change (Figure 6e) 10 minutes after irradiation, and no phototoxicity could be observed after $4 \mathrm{~h}$ (Figure 6f). These experiments attested the capacity of folic acid-conjugated PS $\mathbf{1}$ to induce high phototoxicity following a short two-photon excitation in the near-infrared.
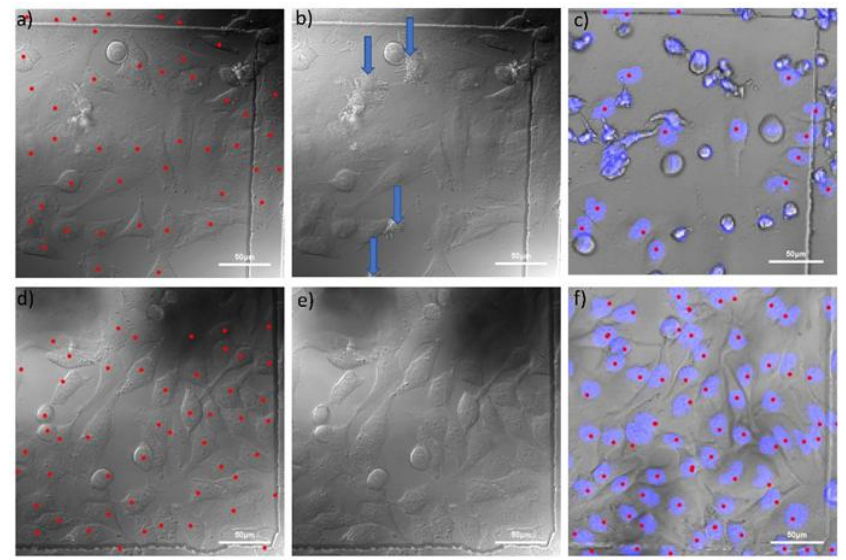

Figure 6. DIC images of HeLa cells incubated $24 \mathrm{~h}$ with ( $a, b$ and $c$ ) or without (d, and f) $1(1 \mu \mathrm{M})$. DIC Images taken before two-photon irradiation ( $a$ and d), images taken $10 \mathrm{~min}$ after irradiation ( $\mathrm{b}$ and e) and images taken $4 \mathrm{~h}$ after irradiation ( $c$ and $\mathrm{f}$ ). For the images taken $4 \mathrm{~h}$ after irradiation, the nuclei of HeLa cells were marked with Hoechst to make counting easier. Living cells are highlighted with red dots. Cell morphology modifications are highlighted with blue arrows. Scale bar is $50 \mu \mathrm{m}$.

\section{Conclusions}

Two targeted PSs were synthesized, characterized and their phototoxicity was evaluated on cancer cells in the context of PDT. They consist of a $\pi$-delocalized diketopyrrolopyrroleporphyrin conjugate linked to folic acid or biotin, for selective delivery of the PSs to cancer cells that overexpressed the receptors of these ligands. Both targeted PSs exhibit a high molar extinction coefficient in the red $\left(60000 \mathrm{M}^{-1} . \mathrm{cm}^{-1}\right.$ in DMSO at $670 \mathrm{~nm}$ ), a high two-photon absorption cross-section in the near-infrared (around $1000 \mathrm{GM}$ at $940 \mathrm{~nm}$ in DMSO) and efficient singlet oxygen generation (close to $70 \%$ in DMSO). For the biotin-targeted PS, we could not detect an increase of its internalization in HeLa cells, indicating that the recognition of the biotin receptor was not effective. On the other hand, the folate-targeted PS showed a high affinity for HeLa cells mediated by the overexpressed folate receptors. The photodynamic activity of both targeted PSs at low micromolar incubation concentration following one-photon excitation at $660 \mathrm{~nm}$ has shown that both exhibit a higher phototoxicity towards HeLa cells than the related non-targeted PS. The twophoton induced toxicity was also assessed with the most promising folate-targeted PS, and irradiation in the optical therapeutic window at $920 \mathrm{~nm}$ for $3 \mathrm{~min}$ led to a good phototoxicity of $60 \%$. Therefore, the folic acid-conjugated PS is a promising PDT agent for active targeting folate receptors overexpressed by many tumour cells. It is not only efficient following one-photon excitation in the red, but also following a more accurate two-photon excitation in the near-infrared. These results are promising for further development of targeted PSs to treat small localized tumours and also deeper tumours. Such applications are of high interest since targeted two-photon PDT could be applied to micrometastasis of margin tissue after tumour resection, to improve the prognosis of the patients.

\section{Experimental}

All reagents and starting chemicals were of the best commercially available grade and used without further purification. The compounds 4-iodobenzoic acid and folic acid were purchased from Acros Organics. The compound D-Biotin was purchased from Fischer BioReagants. Tetrahydrofuran was dried by distillation over sodium and benzophenone. Dry chloroform and dichloromethane were obtained by distillation over $\mathrm{CaH}_{2}$ under argon. Analytical thin layer chromatography (TLC) was carried out on Merck aluminium backed silica gel 60 F254 plates and visualization when required was achieved using UV light. Column chromatography purifications were carried out on silica (VWR chemicals, 60-200 mesh). Sizeexclusion chromatography was carried out using Bio-Beads SX1, 200-400 mesh (Bio-Rad). HPLC was carried out on a Knauer apparatus equipped with a C18 semi-prep or analytical column and UV detector. NMR spectra were recorded using Bruker 
AVANCE 300, 400 or 500 spectrometers. Chemical shifts are quoted as parts per million (ppm) relative to the residual peak of solvent and coupling constants $(J)$ are quoted in Hertz $(\mathrm{Hz})$. To achieve full assignment of the signals the 2D-NMR techniques COSY, NOESY and ROESY have been used. In the assignments, the chemical shift (in ppm) is given first, followed, in brackets, by the multiplicity of the signal ( $\mathrm{s}$ : singlet, $\mathrm{d}$ : doublet, $\mathrm{t}$ : triplet, $\mathrm{m}$ : multiplet, $\mathrm{br} \mathrm{s}$ : broad signal), the number of protons implied, the value of the coupling constants in hertz if applicable, and finally the assignment. The UVIKON XL spectrophotometer was used to record UV-vis spectra. Mass spectra were obtained by using a Bruker MicroTOF spectrometer (ES-MS).

Compounds $3^{56}$ and $5^{47}$ were prepared according to the literature.

\section{Compound 4}

To a solution of 4-iodobenzoic acid (154 $\mathrm{mg}, 0.62 \mathrm{mmol}$ ) dissolved in anhydrous DMF $(3 \mathrm{~mL})$ were added TBTU $(214 \mathrm{mg}$, $0.66 \mathrm{mmol}$ ) followed by DIPEA ( $230 \mu \mathrm{L}, 1,35 \mathrm{mmol})$. A solution of 3 (157 mg, $0.63 \mathrm{mmol}$ ) dissolved in anhydrous DMF $(1.5 \mathrm{~mL})$ was added and the resulting solution was stirred at room temperature for $4 \mathrm{~h}$. The solvents were removed under vacuum and the residue dissolved in $\mathrm{CH}_{2} \mathrm{Cl}_{2}(40 \mathrm{~mL})$. The organic phase was washed with a saturated solution of $\mathrm{NaHCO}_{3}(40 \mathrm{~mL}), \mathrm{HCl} 2 \mathrm{M}(40 \mathrm{~mL})$ and $\mathrm{H}_{2} \mathrm{O}(25 \mathrm{~mL})$. Finally the product was purified by flash chromatography on silica gel (DCM / MeOH 0 to 5\%) to give a pale yellow oil (247 mg, $83 \%$ ). ${ }^{1} \mathrm{H}$ NMR $\left(400 \mathrm{MHz}, \mathrm{CDCl}_{3}, 333 \mathrm{~K}\right): \delta(\mathrm{ppm})=1.45(\mathrm{~s}, 9 \mathrm{H}, t \mathrm{Bu})$, $3.29(\mathrm{td}, J=5.8,5.0 \mathrm{~Hz}, 2 \mathrm{H}, \mathrm{H} 31), 3.55(\mathrm{t}, J=5.3 \mathrm{~Hz}, 2 \mathrm{H}, \mathrm{H} 30)$, 3.62-3.70 (m, 8H, H26, H27, H28, H29,), 7.54 (d, $J=7.4 \mathrm{~Hz}, 2 \mathrm{H}$, $\left.\mathrm{m}^{\prime \prime}\right), 7.78\left(\mathrm{~d}, J=7.4 \mathrm{~Hz}, 2 \mathrm{H}, \mathrm{o}^{\prime \prime}\right)$.

${ }^{13} \mathrm{C}$ NMR $\left(125 \mathrm{MHz}, \mathrm{CDCl}_{3}, 295 \mathrm{~K}\right) \delta(\mathrm{ppm})=28.4,39.8$, 40.3, 69.7, 70.1, 70.2, 70.9, 77.0, 79.5, 98.4, 128.6, $129.2,133.9,137.7,156.0,166.7$.

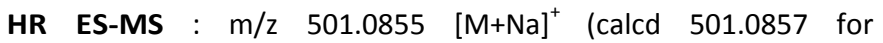
$\left[\mathrm{C}_{18} \mathrm{H}_{27} / \mathrm{N}_{2} \mathrm{NaO}_{5}\right]^{+}$)

\section{Compound 6}

Compounds 4 (7.7 mg, $16 \mu \mathrm{mol}), 5(23.0 \mathrm{mg}, 13.4 \mu \mathrm{mol})$, $\mathrm{Pd}\left(\mathrm{PPh}_{3}\right)_{4}(3.9 \mathrm{mg}, 3.4 \mu \mathrm{mol})$ and $\mathrm{Cul}(0.6 \mathrm{mg}, 3.4 \mu \mathrm{mol})$ were dried under vacuum for $1 \mathrm{~h}$ at $40^{\circ} \mathrm{C}$. A solution of dry THF (5 $\mathrm{mL})$ and $\mathrm{NH}(\mathrm{iPr})_{2}(1 \mathrm{~mL})$ degassed by four freeze-thaw cycles was transferred by cannula to the solids. The reaction mixture was stirred at room temperature and under argon for $2 \mathrm{~h}$. The solvents were removed and the crude was purified by chromatography on silica gel (DCM / MeOH 1.5 to $4.5 \%$ followed by size exclusion column chromatography (Biobeads SX-1, DCM / $1 \%$ pyridine) to give a brown solid in $75 \%$ yield (21 mg).

${ }^{1} \mathbf{H}$ NMR $\left(500 \mathrm{MHz}, \mathrm{CDCl}_{3} /\right.$ pyridine, $\left.295 \mathrm{~K}\right): \delta(\mathrm{ppm})=1.42(\mathrm{~s}$, $9 \mathrm{H}, \mathrm{Boc}), 3.29(\mathrm{~s}, 12 \mathrm{H}, 1), 3.33(\mathrm{~s}, 3 \mathrm{H}, \mathrm{H} 25), 3.34(\mathrm{~m}, 2 \mathrm{H}, \mathrm{H} 31)$, 3.39 (s, 3H, H2O), 3.43-3.50 (m, 10H, H2, H24), 3.50-3.53 (m, $2 \mathrm{H}, \mathrm{H} 19), 3.53-3.64(\mathrm{~m}, 14 \mathrm{H}, \mathrm{H} 3, \mathrm{H} 18, \mathrm{H} 23, \mathrm{H} 30), 3.64-3.70(\mathrm{~m}$, $12 \mathrm{H}, \mathrm{H} 4, \mathrm{H} 28, \mathrm{H} 29)$, 3.70-3.74 (m, 4H, H26, H27), 3.74-3.79 (m,
$10 \mathrm{H}, \mathrm{H} 5, \mathrm{H} 20), 3.83(\mathrm{~m}, 2 \mathrm{H}, \mathrm{H} 21), 3.92(\mathrm{~m}, 8 \mathrm{H}, \mathrm{H} 6), 4.06(\mathrm{~m}$, $2 \mathrm{H}, \mathrm{H} 16), 4.31(\mathrm{~m}, 8 \mathrm{H}, \mathrm{H} 7), 5.13(\mathrm{br}, 1 \mathrm{H}, \mathrm{HA}), 6.93(\mathrm{t}, J=1.9 \mathrm{~Hz}$, $2 \mathrm{H}, \mathrm{p}), 7.10(\mathrm{br}, 1 \mathrm{H}, \mathrm{HB}), 7.36(\mathrm{~d}, J=1.9 \mathrm{~Hz}, \mathrm{o}), 7.51(\mathrm{~m}, 3 \mathrm{H}$, $\mathrm{mpx}, \mathrm{ppx}), 7.99\left(\mathrm{~m}, 4 \mathrm{H}, \mathrm{o}^{\prime \prime}, \mathrm{m}^{\prime \prime}\right), 8.04(\mathrm{~m}, 2 \mathrm{H}, \mathrm{opx}), 8.12(\mathrm{~d}, J=$ $\left.8.2 \mathrm{~Hz}, \mathrm{o}^{\prime}\right), 8.24\left(\mathrm{~d}, J=8.2 \mathrm{~Hz}, \mathrm{p}^{\prime}\right), 8.93(\mathrm{~d}, J=4.4 \mathrm{~Hz}$, py2 or py3), $8.94(d, J=4.4 \mathrm{~Hz}$, py2 or py3), $9.66(\mathrm{~d}, J=4.4 \mathrm{~Hz}$, py1 or py4), $9.67(d, J=4.4 \mathrm{~Hz}$, py1 or py 4$)$.

${ }^{13} \mathrm{C}$ NMR (125 MHz, CDCl$/$ pyridine, $\left.295 \mathrm{~K}\right) \delta(\mathrm{ppm})=28.4,29.7$, 39.9, 40.3, 42.0, 42.4, 59.0, 59.0, 59.1, 67.7, 68.8, 69.0, 69.8, 70.1, 70.2, 70.4, 70.5, 70.6, 70.8, 71.8, 71.8, 79.3, 95.5, 95.8, $96.0,96.5,100.4,100.9,109.7,110.0,114.7,122.5,127.2$, $127.4,127.9,128.8,129.3,129.6,130.5,130.6,131.2,131.4$, 131.6, 132.6, 132.6, 133.7, 135.9, 144.3, 148.3, 149.2, 149.8, $151.9,152.0,156.0,157.8,162.9,163.0,166.9$.

HR ES-MS : m/z $1053.4129[\mathrm{M}+2 \mathrm{Na}]^{2+} / 2$ (calcd 1053.4139 for $\left[\mathrm{C}_{110} \mathrm{H}_{132} \mathrm{~N}_{8} \mathrm{O}_{27} \mathrm{ZnNa}_{2}\right]^{2+} / 2$ ).

\section{Compound 7}

To a solution of $6(47.0 \mathrm{mg}, 22.8 \mu \mathrm{mol})$ in $\mathrm{CH}_{2} \mathrm{Cl}_{2}(10 \mathrm{~mL})$ cooled to $0^{\circ} \mathrm{C}$ was added dropwise TFA $(0.5 \mathrm{~mL}, 6.53 \mathrm{mmol})$. The solution was stirred for $4 \mathrm{~h}$ at room temperature and washed with $\mathrm{H}_{2} \mathrm{O}(15 \mathrm{~mL})$ followed by a saturated aqueous solution of $\mathrm{Na}_{2} \mathrm{CO}_{3}(15 \mathrm{~mL})$. The solvents were dried with anhydrous $\mathrm{Na}_{2} \mathrm{SO}_{4}$ and evaporated under vacuum. To the resulting solid dissolved in $\mathrm{CHCl}_{3}(10 \mathrm{~mL})$ was added dropwise a solution of $\mathrm{Zn}(\mathrm{OAc})_{2} .2 \mathrm{H}_{2} \mathrm{O}(15.7 \mathrm{mg}, 71.5 \mu \mathrm{mol})$ dissolved in $\mathrm{MeOH}(0.5 \mathrm{~mL})$. The solution was stirred at $45{ }^{\circ} \mathrm{C}$ overnight and the solvents were evaporated under reduced pressure. The solid was redissolved in $\mathrm{CH}_{2} \mathrm{Cl}_{2}(20 \mathrm{~mL})$ and washed with a saturated solution of $\mathrm{NaCl}(20 \mathrm{~mL})$ followed by $\mathrm{H}_{2} \mathrm{O}(20 \mathrm{~mL})$. The organic phase was dried with anhydrous $\mathrm{Na}_{2} \mathrm{SO}_{4}$ and the solvent was evaporated under reduced pressure. 7 was obtained as a brown-green solid in $97 \%$ yield (43.2 mg).

${ }^{1} \mathbf{H}$ NMR (500 MHz, CDCl $3 /$ pyridine, $\left.295 \mathrm{~K}\right): \delta(\mathrm{ppm})=3.27(\mathrm{~s}$, $12 \mathrm{H}, \mathrm{H} 1), 3.30(\mathrm{~s}, 3 \mathrm{H}, \mathrm{H} 25), 3.36(\mathrm{~s}, 3 \mathrm{H}, \mathrm{H} 20), 3.41-3.47(\mathrm{~m}$, $12 \mathrm{H}, \mathrm{H} 2, \mathrm{H} 24, \mathrm{H} 31), 3.47-3.54(\mathrm{~m}, 6 \mathrm{H}, \mathrm{H} 19, \mathrm{H} 23, \mathrm{H} 30), 3.57-$ $3.62(m, 12 H, H 3, H 18, H 29), 3.62-3.68(m, 10 H, H 4, H 28)$, 3.67-3.71 (m, 4H, H26, H27), 3.71-3.77 (m, 10H, H5, H22), 3.81 $(\mathrm{m}, 2 \mathrm{H}, \mathrm{H} 17), 3.90(\mathrm{~m}, 8 \mathrm{H}, \mathrm{H} 6), 3.97(\mathrm{~m}, 2 \mathrm{H}, \mathrm{H} 21), 4.04(\mathrm{~m}, 2 \mathrm{H}$, $\mathrm{H} 16), 4.28(\mathrm{~m}, 8 \mathrm{H}, \mathrm{H} 7), 6.92(\mathrm{t}, J=1.9 \mathrm{~Hz}, 2 \mathrm{H}, \mathrm{p}), 7.34(\mathrm{~d}, J=1.9$ $\mathrm{Hz}, \mathrm{o}), 7.48(\mathrm{~m}, 3 \mathrm{H}, \mathrm{mpx}, \mathrm{ppx}), 7.97\left(\mathrm{~m}, 4 \mathrm{H}, \mathrm{o}^{\prime \prime}, \mathrm{m}^{\prime \prime}\right), 8.04(\mathrm{~m}$, $2 \mathrm{H}, \mathrm{opx}), 8.10\left(\mathrm{~d}, J=8.2 \mathrm{~Hz}, 2 \mathrm{H}, \mathrm{o}^{\prime}\right), 8.21\left(\mathrm{~d}, J=8.2 \mathrm{~Hz}, 2 \mathrm{H}, \mathrm{m}^{\prime}\right)$, $8.91(\mathrm{~d}, J=4.4 \mathrm{~Hz}, 2 \mathrm{H}$, py2 or py3), $8.93(\mathrm{~d}, J=4.4 \mathrm{~Hz}, 2 \mathrm{H}$, py 2 or py3), 9.64 (d, $J=4.4 \mathrm{~Hz}, 2 \mathrm{H}$, py1 or py 4$), 9.66(\mathrm{~d}, J=4.4 \mathrm{~Hz}$, $2 \mathrm{H}, \mathrm{py} 1$ or py4).

${ }^{13} \mathrm{C}$ NMR (125 MHz, $\mathrm{CDCl}_{3} /$ pyridine, $\left.295 \mathrm{~K}\right) \delta(\mathrm{ppm})=14.1$, 22.7, 29.3, 29.7, 31.9, 39.9, 41.5, 42.0, 42.4, 59.0, 59.0, 59.1, $67.8,68.9,69.0,69.8,70.1,70.3,70.4,70.5,70.6,70.8,71.9$, $72.9,95.6,95.8,96.1,96.5,100.4,100.9,109.8,110.0,114.7$, $122.5,127.2,127.4,127.5,128.0,128.8,129.3,129.7,130.6$, $131.2,131.4,131.7,132.7,133.9,144.3,148.3,149.9,152.0$, 152.1, 157.8, 162.9, 163.0, 167.0.

HR ES-MS : $\mathrm{m} / \mathrm{z} 992.3889[\mathrm{M}+\mathrm{H}+\mathrm{Na}]^{2+} / 2$ (calcd 992.3967 for $\left[\mathrm{C}_{105} \mathrm{H}_{125} \mathrm{~N}_{8} \mathrm{O}_{25} \mathrm{ZnNa}\right]^{2+} / 2$ ). 


\section{Compound 1}

To a solution of commercial folic acid $(5.4 \mathrm{mg}, 12.2 \mu \mathrm{mol})$ in DMSO $(2 \mathrm{~mL})$ and DMF $(2 \mathrm{~mL})$ cooled to $0^{\circ} \mathrm{C}, \mathrm{N}$ methylmorpholine ( $3 \mu \mathrm{L}, 27 \mu \mathrm{mol}$ ) and TBTU $(3.8 \mathrm{mg}, 11 \mu \mathrm{mol})$ were added. After stirring at $0^{\circ} \mathrm{C}$ for $1 \mathrm{~h}$, a solution of 7 (24.0 $\mathrm{mg}, 12.2 \mu \mathrm{mol})$ in DMF $(2 \mathrm{~mL})$ was added and further stirring of the solution was performed for $20 \mathrm{~h}$ at room temperature. The reaction mixture was poured in $\mathrm{Et}_{2} \mathrm{O}$ and the precipitate washed with $\mathrm{Et}_{2} \mathrm{O}, \mathrm{H}_{2} \mathrm{O}$ and $\mathrm{CH}_{3} \mathrm{CN}$. The crude compound was purified by a C18 HPLC column (injection in DMSO, ammonium acetate $(0.1 \mathrm{M}, \mathrm{pH}=7.2) / \mathrm{CH}_{3} \mathrm{CN} 95 / 5$ for 5 min then a linear gradient until $30 / 70$ in $25 \mathrm{~min}$ followed by $30 / 70$ for $30 \mathrm{~min}$ ). The salts were removed with water to give a brown-green solid in $35 \%$ yield $(10.30 \mathrm{mg}$ ). The purity was found to be $\sim 97 \%$ by HPLC analysis.

${ }^{1}$ H NMR (400 MHz, DMSO-d6, $\left.350 \mathrm{~K}\right): \delta(\mathrm{ppm})=1.94(\mathrm{~m}, 1 \mathrm{H}$, A), $2.03(\mathrm{~m}, 1 \mathrm{H}, \mathrm{B}), 2.17-2.31(\mathrm{~m}, 2 \mathrm{H}, \mathrm{C}), 3.21(\mathrm{~s}, 12 \mathrm{H}, \mathrm{H} 1), 3.23$ $(\mathrm{s}, 3 \mathrm{H}, \mathrm{H} 25), 3.27(\mathrm{~s}, 3 \mathrm{H}, \mathrm{H} 20), 3.35-3.72\left(\mathrm{~m}, 56 \mathrm{H}, \mathrm{O}-\mathrm{CH}_{2}\right) 3.85-$ $3.92(\mathrm{~m}, 8 \mathrm{H}, \mathrm{H} 6)$, $3.94(\mathrm{~m}, 2 \mathrm{H}, \mathrm{H} 21), 4.02(\mathrm{~m}, 2 \mathrm{H}, \mathrm{H} 16), 4.33-$ $4.43(\mathrm{~m}, 9 \mathrm{H}, \mathrm{H} 7, \mathrm{D}), 4.48(\mathrm{~m}, 2 \mathrm{H}, \mathrm{E}), 6.68(\mathrm{~d}, J=8.3 \mathrm{~Hz}, 2 \mathrm{H}, \mathrm{F})$, $7.05(\mathrm{t}, J=2.2 \mathrm{~Hz}, 2 \mathrm{H}, \mathrm{p}), 7.37(\mathrm{~d}, J=2.2 \mathrm{~Hz}, 4 \mathrm{H}, \mathrm{o}), 7.61(\mathrm{~m}, 4 \mathrm{H}$, $\mathrm{mpx}, \mathrm{ppx}), 7.68(\mathrm{~d}, J=8.3 \mathrm{~Hz}, 2 \mathrm{H}, \mathrm{l}), 7.96(\mathrm{~m}, 2 \mathrm{H}, \mathrm{opx}), 8.09-$ $8.20\left(\mathrm{~m}, 4 \mathrm{H}, \mathrm{o}^{\prime \prime}, \mathrm{m}^{\prime \prime}\right), 8.22\left(\mathrm{~d}, J=8.2 \mathrm{~Hz}, 2 \mathrm{H}, \mathrm{o}^{\prime}\right), 8.28(\mathrm{~d}, J=8.2$ $\left.\mathrm{Hz}, 2 \mathrm{H}, \mathrm{m}^{\prime}\right), 8.63(\mathrm{~s}, 1 \mathrm{H}, \mathrm{K}), 8.93(\mathrm{~d}, J=4.7 \mathrm{~Hz}, 2 \mathrm{H}, \mathrm{py} 2$ or py3), $8.94(\mathrm{~d}, J=4.7 \mathrm{~Hz}, 2 \mathrm{H}$, py 2 or py3), $9.73(\mathrm{~d}, J=4.7 \mathrm{~Hz}, 2 \mathrm{H}$, py 1 or py 4$), 9.74(d, J=4.7 \mathrm{~Hz}, 2 \mathrm{H}$, py1 or py 4$)$.

${ }^{13} \mathrm{C}$ NMR (125 MHz, DMSO-d6, $\left.298 \mathrm{~K}\right) \delta(\mathrm{ppm})=27.5,28.7$, 29.5, 31.2, 39.0, 41.8, 42.0, 46.3, 58.5, 58.6, 58.6, 68.1, 68.3, $68.5,69.4,69.4,69.5,70.0,70.1,70.3,70.5,71.6,71.7,71.7$, $95.1,95.2,96.1,96.4,96.6,100.2,100.5,101.2,109.3,109.7$ $111.6,111.7,114.7,123.0,126.2,126.3,128.1,128.2,128.3$, $129.2,129.5,130.1,131.4,131.8,132.1,133.3,134.5,144.1$, $148.0,149.2$, 149.7, 149.8, 151.2, 151.8, 151.8, 158.2, 162.3, 166.1, 166.7.

HR ES-MS : $\mathrm{m} / \mathrm{z} 2384.9311[\mathrm{M}+\mathrm{H}]^{+}$(calcd 2384.9333 for $\left[\mathrm{C}_{124} \mathrm{H}_{142} \mathrm{~N}_{15} \mathrm{O}_{30} \mathrm{Zn}\right]^{+}$).

UV-Vis (DMSO): $\lambda_{\max }(\log \varepsilon)=457$ (5.38), 522sh, 592sh, 617sh, $668 \mathrm{~nm}(4.79)$

\section{Compound 2}

Commercial D-biotin (3.7 mg, $15 \mu \mathrm{mol})$ and TBTU $(4.3 \mathrm{mg}, 13$ $\mu \mathrm{mol})$ were dissolved in DMF $(2 \mathrm{~mL})$ and the solution was stirred at room temperature for $15 \mathrm{~min}$. A solution of $7(20.0$ $\mathrm{mg}, 10.2 \mu \mathrm{mol}$ ) in DMF ( $3 \mathrm{~mL}$ ) was added dropwise and the solution was stirred at room temperature for $20 \mathrm{~h}$. The solvent was removed and the residue was purified by flash chromatography on silica gel (DCM/MeOH, 0 to $8 \%$ ) followed by a $\mathrm{C} 18 \mathrm{HPLC}$ column $\left(\mathrm{H}_{2} \mathrm{O} / \mathrm{CH}_{3} \mathrm{CN}, 50 / 50\right.$ to $30 / 70$ gradient in $30 \mathrm{~min}$ followed by $30 / 70$ for $30 \mathrm{~min}$ at a flow rate of 2 $\mathrm{mL} / \mathrm{min}$ ) to give a brown-green solid in $82 \%$ yield (18 $\mathrm{mg})$. The purity was found to be $\sim 95 \%$ by HPLC analysis.

${ }^{1}$ H NMR (300 MHz, DMSO-d6, $\left.298 \mathrm{~K}\right): \delta(\mathrm{ppm})=1.18-1.35(\mathrm{~m}$, $2 \mathrm{H}, \mathrm{B} 12$ or $\mathrm{B} 13$ or $\mathrm{B} 14), 1.36-1.64(\mathrm{~m}, 4 \mathrm{H}, \mathrm{B} 12$ or $\mathrm{B} 13$ or $\mathrm{B} 14)$, $2.07(\mathrm{~m}, 2 \mathrm{H}, \mathrm{B} 15), 2.53(\mathrm{~m}, 1 \mathrm{H}, \mathrm{B} 6), 2.75(\mathrm{~m}, 1 \mathrm{H}, \mathrm{B} 6), 3.03(\mathrm{~m}$,
$1 \mathrm{H} \mathrm{B8}), 3.17(\mathrm{~s}, 12 \mathrm{H}, \mathrm{H} 1), 3.19(\mathrm{~s}, 3 \mathrm{H}, \mathrm{H} 25), 3.23(\mathrm{~s}, 3 \mathrm{H}, \mathrm{H} 20)$, 3.26-3.66 (m, 56H, O-CH $\mathrm{CH}_{2}, 3.84(\mathrm{~m}, 8 \mathrm{H}, \mathrm{H} 6), 3.91(\mathrm{~m}, 2 \mathrm{H}, \mathrm{H} 21)$, $3.99(\mathrm{~m}, 2 \mathrm{H}, \mathrm{H} 16), 4.06(\mathrm{~m}, 1 \mathrm{H}, \mathrm{B} 10), 4.22(\mathrm{~m}, 1 \mathrm{H}, \mathrm{B} 11), 4.33$ $(\mathrm{m}, 8 \mathrm{H}, \mathrm{H7}), 6.30(\mathrm{~s}, 1 \mathrm{H}, \mathrm{B} 4), 6.37(\mathrm{~s}, 1 \mathrm{H}, \mathrm{B} 2), 7.04(\mathrm{t}, J=1.9 \mathrm{~Hz}$, $2 \mathrm{H}, \mathrm{p}), 7.35(\mathrm{~d}, J=1.9 \mathrm{~Hz}, 4 \mathrm{H}, \mathrm{o}), 7.60(\mathrm{~m}, 3 \mathrm{H}, \mathrm{mpx}, \mathrm{ppx}), 7.83$ $(\mathrm{m}, 1 \mathrm{H}, \mathrm{HA}), 7.96(\mathrm{~m}, 2 \mathrm{H}, \mathrm{opx}), 8.10\left(\mathrm{~d}, J=8.2 \mathrm{~Hz}, 2 \mathrm{H}, \mathrm{o}^{\prime},\right)^{\prime}, 8.21$ $\left(\mathrm{m}, 4 \mathrm{H}, \mathrm{o}^{\prime \prime}, \mathrm{m}^{\prime \prime}\right), 8.29\left(\mathrm{~d}, J=8.2 \mathrm{~Hz}, 2 \mathrm{H}, \mathrm{m}^{\prime}\right), 8.75(\mathrm{~m}, 1 \mathrm{H}, \mathrm{HB})$, $8.91(\mathrm{~d}, J=4.4 \mathrm{~Hz}, 2 \mathrm{H}$, py2 or py3), $8.93(\mathrm{~d}, J=4.4 \mathrm{~Hz}, 2 \mathrm{H}$, py2 or py3), 9.74 (d, $J=4.4 \mathrm{~Hz}, 2 \mathrm{H}$, py1 or py 4$), 9.76(\mathrm{~d}, J=4.4 \mathrm{~Hz}$, $2 \mathrm{H}$, py1 or py4).

${ }^{13}$ C NMR (125 MHz, DMSO-d6, $\left.298 \mathrm{~K}\right) \delta(\mathrm{ppm})=25.7,28.5$, 28.7, 35.6, 38.9, 55.9, 58.5, 58.6, 58.6, 59.6, 61.5, 68.1, 68.3, $68.5,69.4,69.5,69.7,70.0,70.1,70.3,70.5,71.6,71.7,71.7$, $95.2,100.3,100.5,101.2,109.3,109.7,114.8,123.0,126.2$, $126.3,128.1,128.2,128.3,129.2,129.5,130.0,131.4,131.8$, $132.1,133.2,133.2,144.1,148.0,149.2,149.8,151.8,151.9$, 158.2, 162.3, 163.1, 166.1, 172.6 .

HR ES-MS : $\mathrm{m} / \mathrm{z} 1105.4292[\mathrm{M}+\mathrm{H}+\mathrm{Na}]^{2+} / 2$ (calcd 1105.4355 for $\left.\left[\mathrm{C}_{115} \mathrm{H}_{139} \mathrm{~N}_{10} \mathrm{O}_{27} \mathrm{SZnNa}\right]^{2+} / 2\right)$.

UV-Vis (DCM): $\lambda_{\max }(\log \varepsilon)=455$ (5.31), 520sh, 592sh, 620sh, $666 \mathrm{~nm}$ (4.76). (DMSO): $\lambda_{\max }(\log \varepsilon)=456$ (5.32), 520sh, 596sh, $620 \mathrm{sh}, 670 \mathrm{~nm}$ (4.79).

\section{One-photon spectroscopy and photophysics}

Spectroscopic grade DMSO was purchased from Carlo Erba. Pyridine, 1,3-diphenylisobenzofuran (DPBF) and Znphthalocyanine $(\mathrm{ZnPc})$ were from Aldrich. $\mathrm{H}_{2} \mathrm{O}$ was tridistilled (Millipore Milli-Q). Absorption spectra were recorded with a PerkinElmer Lambda 650 UV-vis spectrophotometer.

Emission spectra were collected using a FLS920 fluorimeter (Edinburgh) equipped with a Hamamatsu R5509-72 InP/InGaAs photomultiplier tube supercooled at $193 \mathrm{~K}$ in a liquid nitrogen cooled housing and a TM300 emission monochromator with a NIR grating blazed at $1000 \mathrm{~nm}$ (sensitivity range: 300-1700 $\mathrm{nm}$ ). The spectra have been corrected for the wavelength dependent phototube response. The fluorescence quantum yields have been determined with reference to DPP-ZnP-DPP in aerated DCM $\left(\phi_{\mathrm{fl}}=0.16\right) .{ }^{49}$

Fluorescence lifetimes were measured with an IBH Time Correlated Single Photon Counting apparatus with nanoLED excitation at $465 \mathrm{~nm}$. The analysis of the luminescence decay profiles against time was accomplished with the DAS6 Decay Analysis Software provided by the manufacturer. The fitting has been performed according to function (1):

$\mathrm{l}(\mathrm{t})=\mathrm{b}+\Sigma_{\mathrm{j}} \mathrm{a}_{\mathrm{j}} \mathrm{e}\left(-\mathrm{t} / \tau_{\mathrm{j}}\right)$

The relative amplitude, also known as fractional intensity, is calculated according to equation (2), and expressed as a percentage:

$f_{i}=a_{i} \tau_{i} / \Sigma_{j} a_{j} \tau_{j}$

Estimated errors are $10 \%$ on lifetimes, $20 \%$ on quantum yields, $20 \%$ on molar absorption coefficients and $3 \mathrm{~nm}$ on emission and absorption peaks.

Singlet oxygen production quantum yields in DMSO have been measured with a comparative method using DPBF as a singlet oxygen trap. ZnPc has been used as a standard $\left(\phi_{\Delta}=\right.$ $0.67) .{ }^{72}$ Solutions of the compound or the standard ( $c=2-6 \times$ 
$\left.10^{-6} \mathrm{M}\right)$ containing DPBF $2.2 \times 10^{-5} \mathrm{M}$, prepared in the dark, were irradiated at $672 \mathrm{~nm}$ by using an irradiation setup composed by a $150 \mathrm{~W}$ xenon lamp (LOT) and a Omni- $\lambda 150$ monochromator (Zolix) with a $16 \mathrm{~nm}$ slit, completed by a 635 $\mathrm{nm}$ cutoff filter, under continuous stirring. The light intensity was $1.0 \mathrm{~mW} / \mathrm{cm}^{2}$. The decrease of DPBF absorption, derived by subtracting the constant absorption contribution of the compound or the standard from the spectrum of the mixture, has been followed at $417 \mathrm{~nm}$. The $\phi_{\Delta}$ values were calculated as previously described. ${ }^{47}$

The two compounds showed good thermal and photophysical stability in the explored solvents and under the employed experimental conditions.

\section{Two-photon spectroscopy.}

The two-photon excitation spectra were obtained by upconverted fluorescence measurements using a Ti:sapphire femtosecond laser Insight DS with pulse width $<120 \mathrm{fs}$ and a repetition rate of $80 \mathrm{MHz}$ (Spectra-Physics) as described previously. ${ }^{74}$ The excitation beam was collimated over the cell length $(10 \mathrm{~mm})$ and the fluorescence, collected at $90^{\circ}$ of the excitation beam, was focused into an optical fiber connected to a spectrometer. The incident beam intensity was adjusted to ensure an intensity-squared dependence of the fluorescence over the whole spectral range investigated. Calibration of the spectra was performed by comparison with the published rhodamine $B$ two-photon absorption spectrum. $^{75}$

\section{Cell culture and MTT cell viability test.}

HeLa cells were cultured in DMEM complete culture medium containing phenol red at $37^{\circ} \mathrm{C}$ with $5 \% \mathrm{CO}_{2}$. They were seeded and maintained in $25 \mathrm{~mL}$ Falcon culture flask or multi well LabTek (Lab-Tek ${ }^{\circledR} \mathrm{II}$ ) culture flasks. Cell viability was assessed in pentaplicate by adding a solution of 3-(4,5-dimethyl-2thiazolyl)-2,5-diphenyl-2H-tetrazolium bromide ( $50 \mu \mathrm{L}$ of a 5 $\mathrm{mg} / \mathrm{mL}$ solution in DMEM by well). After an incubation period of 45 minutes, the media was removed and replaced by DMSO $(150 \mu \mathrm{L})$. The absorbance was measured using the Safas Xenius spectrofluorimeter 96 well plates reader at $550 \mathrm{~nm}$.

\section{Dark cytotoxicity}

HeLa cells were seeded in 96 wells culture plates and incubated with different concentrations of 1 or $2(0-12 \mu \mathrm{M}$ in DMEM with 0-0.1\% DMSO), After 24 hours the cell viability was estimated using the MTT test previously described.

\section{Competition assay}

The assays were made as previously described by Frochot et al. for $\mathbf{1}$ and $6,{ }^{56}$ and Lin et al. for $\mathbf{2}^{57}$ HeLa cells were seeded in a $250 \mathrm{~mL}$ culture flask in a complete DMEM medium, as described previously in the cell culture section. Samples of these cultures were incubated with 6, 1 or 2 (1 $\mu \mathrm{M}$ in DMEM with $0.01 \% \mathrm{DMSO}$ ) for $24 \mathrm{~h}$ in presence or in absence of folic acid $(4 \mathrm{mM})$ or biotin $(1 \mathrm{mM})$. These cell cultures were then washed three times with phosphate-buffered saline $(15 \mathrm{~mL})$. Cells were suspended using trypsin $(1 \mathrm{~mL})$, and $9 \mathrm{~mL}$ of DMEM was added. The cells were counted using a Malassez cell. The culture medium was removed by gentle centrifugation at $60 \mathrm{~g}$. The cell pellet was then lyophilized and redissolved in DMSO (1 $\mathrm{mL}$ ). The fluorescence emission was measured and the intensity of each sample was normalized to the cell concentration.

\section{One-photon phototoxicity tests}

One-photon phototoxicity tests were performed as described in the literature using a homemade apparatus ${ }^{46-48}$ with $800 \mathrm{~mA}$ high power LED Deep Red $(640-660 \mathrm{~nm})$ (FutureEden ${ }^{\mathrm{TM}}$ ) adapted for Corning ${ }^{\oplus} 96$ well special optic plates. Cells were cultured 1 day in these 96 well plates and incubated with a solution of PS ( $1 \mu \mathrm{M}$ in DMEM with $0.01 \%$ DMSO) for 24 hours. The medium was replaced by new DMEM free of sensitizer and the plates were irradiated for 15 or $30 \mathrm{~min}$. The LEDs power was measured with a Thorlabs PM100D powermeter. The cell viability was then estimated 24 hours after irradiation using the MTT test previously described.

\section{Two-photon phototoxicity tests}

HeLa cells were plated at $25 \%$ confluence in IBIDI $\mu$-Dish 35 $\mathrm{mm}$, grid-500. After $24 \mathrm{~h}$ growth the culture medium was replaced by a fresh one containing 1 ( $1 \mu \mathrm{M}$ in DMEM with 0.01 $\%$ DMSO). Two-photon irradiation was performed after $24 \mathrm{~h}$ incubation, with a cell confluence of about $80 \%$ using a Leica SP5 inverted microscope with a HCX PL APO CS 40x oil Leica objective and a Coherent Chameleon Ultra 2 laser as fs laser source (150 fs pulses with a repetition rate of $80 \mathrm{MHz}$ set at $920 \mathrm{~nm}$ ). A region of $260 \times 260 \mu \mathrm{m}$ (zoom set to 1.5) was irradiated. The laser power was measured at the back pupil of the objective and set at a laser power of $12 \mathrm{~mW}$. The focus plane was selected by DIC (differential interference contrast) microscopy $\left(\lambda_{\mathrm{ex}}=513 \mathrm{~nm}\right.$ ) to be at the bottom part of the cells. They were irradiated using a series of 10 slices (10 up the selected focal plane corresponding to the coverslip), with $1 \mu \mathrm{m}$ $\mathrm{z}$ increments, with 30 scans per slice (300 scans in total). After irradiation the cells were imaged every 30 seconds during 10 min in wild field DIC to detect morphological changes. Then, the irradiated cells were placed for $3 \mathrm{~h} 30$ in an incubator. Hoescht $33342(5 \mu \mathrm{g} / \mathrm{mL})$ was added and the cells placed in the incubator for another $30 \mathrm{~min}$ before imaging. Confocal images were obtained with a Leica TSP SPE microscope.

\section{Conflicts of interest}

There are no conflicts to declare.

\section{Acknowledgements}


The icFRC (http://www.icfrc.fr), LabEx CSC, are gratefully acknowledged for their support. The Ministry of Education and Research and the University of Strasbourg are acknowledged for a Ph.D. fellowship to S.J. Italian CNR (Project "PHEEL") and MIUR-CNR project Nanomax $\mathrm{N}-\mathrm{CHEM}$ are gratefully acknowledged.

\section{References}

P. Agostinis, K. Berg, K. A. Cengel, T. H. Foster, A. W. Girotti, S. O. Gollnick, S. M. Hahn, M. R. Hamblin, A. Juzeniene, D. Kessel, M. Korbelik, J. Moan, P. Mroz, D. Nowis, J. Piette, B. C. Wilson and J. Golab, CA: A Cancer Journal for Clinicians, 2011, 61, 250-281.

2. D. Van Straten, V. Mashayekhi, H. S. De Bruijn, S. Oliveira and D. J. Robinson, Cancers, 2017, 9, 19.

3. M. Ethirajan, Y. Chen, P. Joshi and R. K. Pandey, Chem. Soc. Rev., 2011, 40, 340-362.

4. A. B. Ormond and H. S. Freeman, Materials, 2013, 6, 817.

5. H. Abrahamse and Michael R. Hamblin, Biochem. J., 2016, 473, 347-364.

6. M. Göppert-Mayer, Annalen der Physik, 1931, 401, 273294.

7. F. Bolze, S. Jenni, A. Sour and V. Heitz, Chem. Commun., 2017, 53, 12857-12877.

8. H. A. Collins, M. Khurana, E. H. Moriyama, A. Mariampillai, E. Dahlstedt, M. Balaz, M. K. Kuimova, M. Drobizhev, V. X. D. Yang, D. Phillips, A. Rebane, B. C. Wilson and H. L. Anderson, Nat. Photonics, 2008, 2, 420-424.

9. M. Gary-Bobo, Y. Mir, C. Rouxel, D. Brevet, I. Basile, M. Maynadier, O. Vaillant, O. Mongin, M. Blanchard-Desce, A. Morère, M. Garcia, J.-O. Durand and L. Raehm, Angew. Chem., Int. Ed., 2011, 50, 11425-11429.

10. J. R. Starkey, A. K. Rebane, M. A. Drobizhev, F. Meng, A. Gong, A. Elliott, K. McInnerney and C. W. Spangler, Clin. Cancer Res., 2008, 14, 6564-6573.

11. B. Gu, W. Wu, G. Xu, G. Feng, F. Yin, P. H. J. Chong, J. Qu, K.-T. Yong and B. Liu, Adv. Mater., 2017, 29, 1701076.

12. W. M. Sharman, J. E. van Lier and C. M. Allen, Adv. Drug Delivery Rev., 2004, 56, 53-76.

13. D. Phillips, Journal, 2011, 83, 733.

14. K. Sato, T. Nagaya, P. L. Choyke and H. Kobayashi, Theranostics, 2015, 5, 698-709.

15. G. Garcia, F. Hammerer, F. Poyer, S. Achelle, M.-P. Teulade-Fichou and P. Maillard, Bioorg. Med. Chem., 2013, 21, 153-165.

16. M. Lupu, P. Maillard, J. Mispelter, F. Poyer and C. D. Thomas, Photochem. Photobiol. Sci., 2018, 17, 1599-1611. S. Yano, M. Naemura, A. Toshimitsu, M. Akiyama, A. Ikeda, J.-i. Kikuchi, X. Shen, Q. Duan, A. Narumi, M. Inoue, K. Ohkubo and S. Fukuzumi, Chem. Commun., 2015, 51, 16605-16608.

18. S. Y. Park, H. J. Baik, Y. T. Oh, K. T. Oh, Y. S. Youn and E. S. Lee, Angew. Chem., Int. Ed., 2011, 50, 1644-1647.

19. Y. Ichikawa, M. Kamiya, F. Obata, M. Miura, T. Terai, T. Komatsu, T. Ueno, K. Hanaoka, T. Nagano and Y. Urano, Angew. Chem., Int. Ed., 2014, 53, 6772-6775.

20. E. H. Khan, H. Ali, H. Tian, J. Rousseau, G. Tessier, Shafiullah and J. E. van Lier, Bioorg. Med. Chem. Lett., 2003, 13, 1287-1290.
21. H. M. Wang, J. Q. Jiang, J. H. Xiao, R. L. Gao, F. Y. Lin and X. Y. Liu, Chem.-Biol. Interact., 2008, 172, 154-158.

22. L. Luan, W. Fang, W. Liu, M. Tian, Y. Ni, X. Chen and X. Yu, Org. Biomol. Chem., 2016, 14, 2985-2992.

23. C. L. Conway, I. Walker, A. Bell, D. J. H. Roberts, S. B. Brown and D. I. Vernon, Photochem. Photobiol. Sci., 2008, 7, 290-298.

24. L. Tirand, C. Frochot, R. Vanderesse, N. Thomas, E. Trinquet, S. Pinel, M.-L. Viriot, F. Guillemin and M. Barberi-Heyob, J. Controlled Release, 2006, 111, 153-164. A. Srivatsan, M. Ethirajan, S. K. Pandey, S. Dubey, X. Zheng, T.-H. Liu, M. Shibata, J. Missert, J. Morgan and R. K. Pandey, Mol. Pharmaceutics, 2011, 8, 1186-1197.

26. M.-R. Ke, J. M. Eastel, K. L. K. Ngai, Y.-Y. Cheung, P. K. S. Chan, M. Hui, D. K. P. Ng and P.-C. Lo, Chem. - Asian J., 2014, 9, 1868-1875.

27. B. G. Ongarora, K. R. Fontenot, X. Hu, I. Sehgal, S. D. Satyanarayana-Jois and M. G. H. Vicente, J. Med. Chem., 2012, 55, 3725-3738.

28. S. Raphael, T. Loraine, F. Celine, V. Regis, T. Noemie, G. Julien, G. Francois and B.-H. Muriel, Anti-Cancer Agents Med. Chem., 2006, 6, 469-488.

29. N. Thomas, D. Bechet, P. Becuwe, L. Tirand, R. Vanderesse, C. Frochot, F. Guillemin and M. BarberiHeyob, J. Photochem. Photobiol., B, 2009, 96, 101-108.

30. M. Shadidi and M. Sioud, Drug Resistance Updates, 2003, 6, 363-371.

31. Y. Li, J. Wang, X. Zhang, W. Guo, F. Li, M. Yu, X. Kong, W. $\mathrm{Wu}$ and Z. Hong, Org. Biomol. Chem., 2015, 13, 76817694.

32. G. Russell-Jones, K. McTavish, J. McEwan, J. Rice and D. Nowotnik, J. Inorg. Biochem., 2004, 98, 1625-1633.

33. S. Sabharanjak and S. Mayor, Adv. Drug Delivery Rev., 2004, 56, 1099-1109.

34.

C. M. Paulos, M. J. Turk, G. J. Breur and P. S. Low, Adv. Drug Delivery Rev., 2004, 56, 1205-1217.

35. A. R. Hilgenbrink and P. S. Low, J. Pharm. Sci., 2005, 94 2135-2146.

36. K. Stefflova, H. Li, J. Chen and G. Zheng, Bioconjugate Chem., 2007, 18, 379-388.

37. J. A. Reddy, V. M. Allagadda and C. P. Leamon, Curr. Pharm. Biotechnol., 2005, 6, 131-150.

38. M.-R. Ke, S.-L. Yeung, D. K. P. Ng, W.-P. Fong and P.-C. Lo, J. Med. Chem., 2013, 56, 8475-8483.

39. P. Couleaud, V. Morosini, C. Frochot, S. Richeter, L. Raehm and J.-O. Durand, Nanoscale, 2010, 2, 1083-1095.

40. Y. Zhou, X. Liang and Z. Dai, Nanoscale, 2016, 8, 1239412405.

41. D. Bechet, P. Couleaud, C. Frochot, M.-L. Viriot, F. Guillemin and M. Barberi-Heyob, Trends Biotechnol., 2008, 26, 612-621.

42. A. M. Bugaj, Photochem. Photobiol. Sci., 2011, 10, 10971109.

F. Hammerer, G. Garcia, S. Chen, F. Poyer, S. Achelle, C. Fiorini-Debuisschert, M.-P. Teulade-Fichou and P. Maillard, J. Org. Chem., 2014, 79, 1406-1417.

44. B. S. Wang, J. Wang and J.-Y. Chen, J. Mater. Chem. B, 2014, 2, 1594-1602.

45. X. Zhao, M. Li, W. Sun, J. Fan, J. Du and X. Peng, Chem. Commun., 2018, 54, 7038-7041.

46. A. Sour, S. Jenni, A. Ortí-Suárez, J. Schmitt, V. Heitz, F. Bolze, P. Loureiro de Sousa, C. Po, C. S. Bonnet, A. Pallier, 
É. Tóth and B. Ventura, Inorg. Chem., 2016, 55, 45454554.

47. J. Schmitt, V. Heitz, A. Sour, F. Bolze, P. Kessler, L. Flamigni, B. Ventura, C. S. Bonnet and É. Tóth, Chem. Eur. J., 2016, 22, 2775-2786.

48. J. Schmitt, S. Jenni, A. Sour, V. Heitz, F. Bolze, A. Pallier, C. S. Bonnet, É. Tóth and B. Ventura, Bioconjugate Chem., 2018, 29, 3726-3738.

49. J. Schmitt, V. Heitz, A. Sour, F. Bolze, H. Ftouni, J.-F. Nicoud, L. Flamigni and B. Ventura, Angew. Chem., Int. Ed., 2015, 54, 169-173.

50. Y. Lu and P. S. Low, Adv. Drug Delivery Rev., 2002, 54, 675693.

51. S. Aurelie, B. Francis, J. Gulim, M. Bauyrzhan and F. Celine, Curr. Med. Chem., 2015, 22, 3185-3207.

52. W. X. Ren, J. Han, S. Uhm, Y. J. Jang, C. Kang, J.-H. Kim and J. S. Kim, Chem. Commun., 2015, 51, 10403-10418.

53. H. Azaïs, C. Schmitt, M. Tardivel, O. Kerdraon, A. Stallivieri, C. Frochot, N. Betrouni, P. Collinet and S. Mordon, Photodiagnosis Photodyn. Ther., 2016, 13, 130-138.

54. A. Stallivieri, L. Colombeau, G. Jetpisbayeva, A. Moussaron, B. Myrzakhmetov, P. Arnoux, S. Acherar, R. Vanderesse and C. Frochot, Bioorg. Med. Chem., 2017, 25, 1-10.

55. J. Gravier, R. Schneider, C. Frochot, T. Bastogne, F. Schmitt, J. Didelon, F. Guillemin and M. Barberi-Heyob, J. Med. Chem., 2008, 51, 3867-3877.

56. R. Schneider, F. Schmitt, C. Frochot, Y. Fort, N. Lourette, F. Guillemin, J.-F. Müller and M. Barberi-Heyob, Bioorg. Med. Chem., 2005, 13, 2799-2808.

57. K. Li, L. Qiu, Q. Liu, G. Lv, X. Zhao, S. Wang and J. Lin, J. Photochem. Photobiol., B, 2017, 174, 243-250.

58. A. D. Gülmez, M. Göksel and M. Durmuş, J. Porphyrins Phthalocyanines, 2017, 21, 547-554.

59. M. Göksel, Bioorg. Med. Chem., 2016, 24, 4152-4164.

60. M. F. Isaac-Lam and D. M. Hammonds, Pharmaceuticals, 2017, 10, 41.

61. J. Zhang, W. Tavares de Sousa Júnior, V. C. Mello da Silva, M. C. Rodrigues, J. A. Vasconcelos Morais, J.-L. Song, Z.-Q. Cheng, J. P. F. Longo, R. Bentes Azevedo, C.-S. Jiang, L. Alexandre MuehImann and H. Zhang, Molecules, 2018, 23, 1436.

62. L. TWB, C. J, B. L, C. W, S. J, W. BC and Z. G, Theranostics, 2011, 1, 354-362.

63. D. Li, P. Li, Z. Jiang and L. Guo, Chem. Lett., 2013, 42, 130131.

64. L. Donghong, W. Dong, D. Junlin and L. Jianchang, Chem. Lett., 2009, 38, 1158-1159.

65. X. Li, C. y. Kim, S. Lee, D. Lee, H.-M. Chung, G. Kim, S.-H. Heo, C. Kim, K.-S. Hong and J. Yoon, J. Am. Chem. Soc., 2017, 139, 10880-10886.

66. X.-Q. Wang, Q. Lei, J.-Y. Zhu, W.-J. Wang, Q. Cheng, F. Gao, Y.-X. Sun and X.-Z. Zhang, ACS Appl. Mater. Interfaces, 2016, 8, 22892-22899.

67. L. Yu, Q. Wang, K.-W. Yeung, W.-P. Fong and P.-C. Lo, Chem. - Asian J., 2018, 13, 3509-3517.

68. K. Li, W. Dong, Q. Liu, G. Lv, M. Xie, X. Sun, L. Qiu and J. Lin, J. Photochem. Photobiol., B, 2019, 190, 1-7.

69. M. M. Alam, F. Bolze, C. Daniel, L. Flamigni, C. Gourlaouen, V. Heitz, S. Jenni, J. Schmitt, A. Sofur and B. Ventura, Phys. Chem. Chem. Phys., 2016, 18, 21954 21965.
K. Mishra and A. Joy, Polymer, 2015, 66, 110-121.

E. S. Nyman and P. H. Hynninen, J. Photochem. Photobiol., B, 2004, 73, 1-28.

A. Ogunsipe, J.-Y. Chen and T. Nyokong, New J. Chem., 2004, 28, 822-827.

D. Li, P. Li, H. Lin, Z. Jiang, L. Guo and B. Li, J. Photochem. Photobiol., B, 2013, 127, 28-37.

A. Hayek, F. Bolze, C. Bourgogne, P. L. Baldeck, P. Didier, Y. Arntz, Y. Mély and J.-F. Nicoud, Inorg. Chem., 2009, 48, 9112-9119.

N. S. Makarov, M. Drobizhev and A. Rebane, Opt. Express, 2008, 16, 4029-4047. 